\title{
Pelatihan Penelitian Tindakan Kelas Kepada Guru SDN 001 Rimba Sekampung Dumai
}

\author{
Hanifatul Rahmi ${ }^{1 *}$, Adelia Alfama Zamista ${ }^{2}$, Juni Saputra ${ }^{3}$ \\ ${ }^{1,2,3}$ Program Studi Teknik Industri, Sekolah Tinggi Teknologi Dumai, Indonesia \\ Email: 1aorrariza89@gmail.com, ${ }^{2}$ alfadelia17@gmail.com, ${ }^{3}$ junisaputr4@gmail.com
}

\section{INFORMASI ARTIKEL}

\section{Data artikel:}

Naskah masuk, 31 Juli 2019

Direvisi, 27 Agustus 2019

Diiterima, 31 Agustus 2019

\section{Kata Kunci:}

Penelitian Tindakan Kelas

Pelatihan Guru

Guru SD

\section{ABSTRAK}

Abstract- The purpose of implementing Community Service is to provide knowledge to teachers which includes: Strategy for writing classroom action research. The material for writing classroom action research strategies begins with introducing the activities that must be carried out by the teacher before classroom action research, explaining to the teacher to find problems that can be raised as research material, solutions that can be used as alternative learning improvements, classroom action research concepts, research designs class action, compiling a proposal for classroom action research proposal, assessing classroom action research reports, student value data is valuable data that can be analyzed and described as main data and describes how to search references from various sources. Participants also received guidance on writing classroom action research on classroom action research tutorials and practice activities. The trainees were 15 teachers from SDN 001 Rimba Sekampung. After training, the results obtained are: Increased teacher's ability to seek effective learning, Understanding Classroom Action Research Concepts, Understanding Classroom Action Research Design Arrangements, Compiling Classroom Action Research Proposals, Can provide assessment of Classroom Action Research reports.

\begin{tabular}{l} 
Abstrak- Tujuan pelaksanaan pengabdian kepada \\
masyarakat adalah memberikan pengetahuan kepada guru \\
yang meliputi: Strategi penulisan penelitian tindakan kelas. \\
Materi strategi penulisan penelitian tindakan kelas dimulai \\
dengan mengenalkan kegiatan yang harus dilakukan guru \\
sebelum penelitian tindakan kelas, memaparkan kepada \\
guru untuk menemukan masalah yang dapat diangkat untuk \\
dijadikan bahan penelitian, solusi yang dapat dijadikan \\
alternatif perbaikan pembelajaran, konsep penelitian \\
tindakan kelas, desain/ rancangan penelitian tindakan kelas, \\
menyusun usulan proposal penelitian tindakan kelas, \\
menilai laporan penelitian tindakan kelas, data-data nilai \\
siswa merupakan data berharga yang dapat dianalisis dan \\
dijabarkan sebagai data utama dan memaparkan cara \\
\hline
\end{tabular}


penelusuran referensi-referensi dari berbagai sumber. Peserta juga mendapatkan bimbingan penulisan penelitian tindakan kelas pada kegiatan tutorial dan praktik penulisan penelitian tindakan kelas. Peserta pelatihan sebanyak 15 orang guru SDN 001 Rimba Sekampung. Setelah pelatihan, hasil yang didapatkan ialah: Meningkatnya kemampuan guru dalam mengupayakan pembelajaran yang efektif, Memahami Konsep Penelitian Tindakan Kelas, Memahami Penyusunan Desain Penelitian Tindakan Kelas, Menyusun Proposal Penelitian Tindakan Kelas, Dapat memberikan penilaian laporan Penelitian Tindakan Kelas.

\section{Korespondensi:}

\section{Hanifatul Rahmi}

Program Studi Teknik Industri, Sekolah Tinggi Teknologi Dumai

Jl. Utama Karya, Bukit Batrem, Dumai Tim., Kota Dumai, Riau, Indonesia

\section{PENDAHULUAN}

Seorang guru dituntut untuk lebih peka terhadap prestasi belajar siswanya. Kepekaan dan sensitivitas inilah yang akan mendorong naluri guru untuk memperbaiki proses pembelajaran. Penelitian tindakan kelas merupakan salah satu solusi utuk memperbaiki proses pembelajaran tersebut. Setelah memahami hakikat PTK, langkah-langkah dalam melakukannya, serta telah merencanakan proposal, maka selanjutnya adalah meneliti tindakan di kelas (Somatanaya \& Herawati, 2017). Selanjutnya laporan penelitian tindakan kelas berarti menuliskan secara detail seluruh kegiatan penelitian.

Berdasarkan hasil wawancara terhadap beberapa guru di sekolah SDN 001 Rimba Sekampung pada tanggal 25 November 2018 diperoleh bahwa pada semester ganjil terdapat beberapa kelas yang belum mencapai ketuntasan maksimal sebesar $85 \%$. Untuk itu perlu dilakukan perbaikan proses pembelajaran yang efektif (Wiganda, 2014). Guru dapat mencoba model-model pembelajaran untuk menyelesaikan permasalahan yang dialami oleh guru untuk meningkatkan hasil belajar siswa (Handayani, Nasikh, \& Annisya', 2017).

Menurut Dini (Mulia \& Suwarno, 2016) tujuan dari penulisan PTK diantaranya adalah mendapat pengalaman nyata untuk memperbaiki pembelajaran yang dapat dijadikan bahan pengembangan kurikulum di kelas dan meningkatkan profesionalisme guru.
Berdasarkan hasil wawancara dengan Guru SDN 001 Rimba Sekampung di Kota Dumai diketahui bahwa guru merasa kurang pengetahuan mengenai cara untuk melakukan penelitian tindakan kelas. Kendala-kendala ini kemudian membuat guru sama sekali tidak termotivasi untuk melakukan penelitian sehingga informasi aspek-aspek pembelajaran dikelas (keunikan, masalah, perkembangan peserta didik) tidak diketahui. Permasalahan yang dihadapi oleh guru-guru tersebut akan menjadi hal yang akan menghambat pencapaian pendidikan yang berkualitas.

Berdasarkan uraian permasalahan di atas perlu dipertimbangkan dilakukan kegiatan pelatihan penelitian tindakan kelas ini bagi para guru, karena keterbatasan waktu, tenaga dan pengetahuan serta kemampuan guru-guru yang dibatasi para guru SDN 001 Rimba Sekampung. Pelatihan difokuskan pada peningkatan kemauan dan kemampuan (motivasi) guru melakukan perbaikan pembelajaran agar efektif melalui modelmodel pembelajaran.

\section{METODE PELAKSANAAN}

Pengabdian ini dilaksanakan di SDN 001 Rimba Sekampung Jln. Semangka No. 3 Kel. Rimba Sekampung Kota Dumai. Pengabdian ini berbentuk penyuluhan, pendampingan dan evaluasi. Guru yang menajdi peserta pelatihan sebanyak 15 Orang. Guru diberikan modul pendamping agar guru mendapatkan informasi 
yang jelas dan terarah dalam menulis penelitian tindakan kelas. Kegiatan dilaksanakan pada tanggal 22-23 Januari 2019. Kegiatan dimulai dari pukul 13.00 dan berakhir pada pukul 16.00 WIB

\section{HASIL DAN PEMBAHASAN}

Program pengabdian masyarakat yang dilakukan berjudul "Pelatihan Penulisan Penelitian Tindakan Kelas". Penunjukan peserta diserahkan kepala kepala sekolah, disarankan guru yang mengikuti pelatihan adalah guru yang sedang mengalami masalah pembelajaran di kelas atau ketuntasan minimal kurang dari $85 \%$. Semua guru yang ditunjuk semuanya menghadiri pelatihan ini. Hal ini menunjukkan respon positif terhadap kegiatan ini.

Materi yang disampaikan dalam pelatihan ini adalah pentingnya penulisan karya tulis ilmiah untuk peningkatan proses pembelajaran yang berdampak pada prestasi siswa, konsep penelitian tindakan kelas, penyusunan desain atau rancangan penelitian tindakan kelas, penilaian terhadap laporan penelitian tindakan kelas. Pemateri terdiri dari 2 orang dosen yang berasal dari anggota TIM PPM ditambah dengan 4 orang dosen lainnya yang berpartisipasi aktif.

Materi yang diberikan disertai satu contoh artikel untuk dibedah perbagiannya. Setelah dilaksanakannya pelatihan, hasil yang didapatkan adalah pemahaman terhadap konsep penulisan tindakan kelas (PTK), menyusun desain /rancangan ptk, menyusun usulan/proposal PTK, dan penggunaan modelmodel pembelajaran sebagai solusi pembelajaran yang efektif. Program pengabdian masyarakat dengan judul "Pelatihan penulisan penelitian tindakan kelas" telah berjalan dengan baik. Pelaksanaan pelatihan diawali dengan kedatangan tim PPM ke SDN 001 Rimba Sekampung pada tanggal 22-23 Januari 2019.

Tim pelaksanaan PKM diterima oleh Ibu Luci Erfianti, S.Pd. seperti terlihat pada gambar 1, selanjutnya dilakukan pembukaan acara pelatihan acara secara bersama antara tim pelaksana kegiatan PKM STT Dumai dengan Kepala Sekolah SDN 001 Rimba Sekampung. Setelah pembukaan berlangsung, dilanjutkan dengan sesi 1 penyampaian materi pertama.

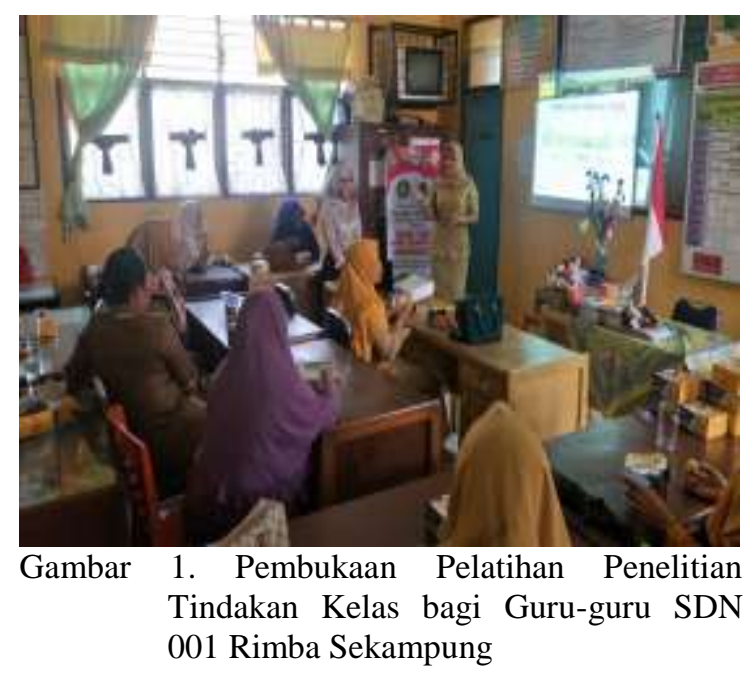

Penelitian tindakan kelas merupakan kegiatan penelitian yang langsung dapat menjawab masalah praktis di sekolah yang dihadapi oleh guru dan siswa, serta sekolah. Kedepan jenis penelitian ini akan mendapat porsi yang cukup besar dalam kegiatan penelitian di bidang pendidikan.

Disaat awal sesi satu dijelaskan mengenai materi urgensi penulisan penelitian tindakan kelas untuk peningkatan pembelajaran yang efektif. Narasumber memberikan materi tujuan untuk menumbuhkan kesadaran kepada guru-guru bahwa guru dituntut untuk lebih peka terhadap prestasi belajar siswanya. Dan terlihat bahwa guru-guru SDN 001 Rimba Sekampung masih belum paham mengenai PTK.

Kegiatan PKM dilanjutkan dengan kegiatan kedua, berupa strategi penulisan PTK. Kegiatan ini berisikan materi sebagai berikut:

a) Memperkenalkan apa itu penelitian tindakan kelas

b) Memperkenalkan bentuk data, sumber data, dan teknik analisis data khususnya untuk penelitian tindakan kelas pendidikan

c) Mengarahkan guru-guru untuk mampu melakukan penelusuran referensi seperti jurnal terkait dengan penelitian yang akan dilakukan

Pada gambar 2 dijelaskan tentang tahapan pengabdian masyarakat yang meliputi kegiatan pelatihan pembuatan Rencana Pembelajaran (RP). Kegiatan hari pertama ditutup setelah sesi kedua ini. Dan guru-guru yang mengikuti 
kegiatan ini mendapat tugas untuk mengumpulkan data-data nilai siswa sebagai data awal penelitian juga mencari literatur yang terkait dengan rencana penelitian yang akan dibuat oleh guru.

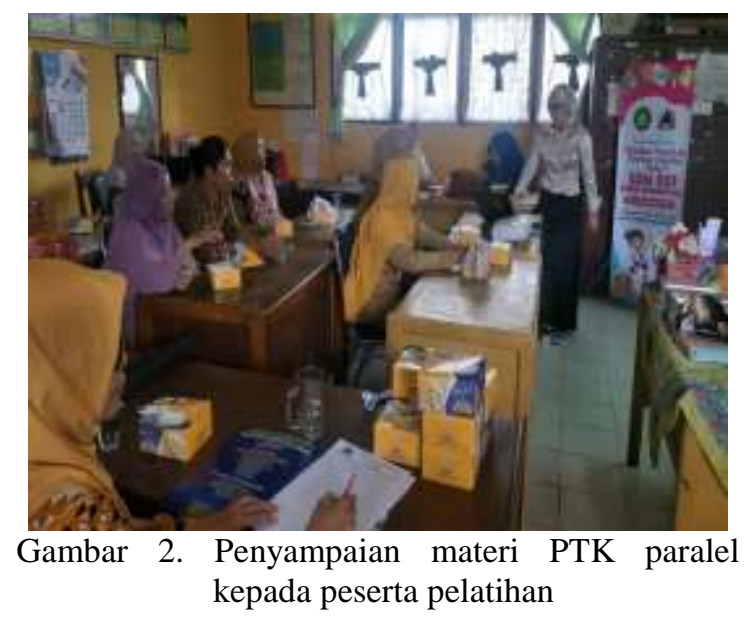

Kegiatan dilanjutkan pada hari kedua Tanggal 23 Januari 2019. Sesi pertama pada hari kedua merupakan materi mengenai rancangan desain penelitian tindakan kelas. Pada saat ini hampir 100\% merupakan pemberian materi oleh tutor mengenai PTK. Kegiatan ini cukup singkat. Saat tutor sudah memastikan semua guru-guru peserta pelatihan paham dengan materi dan siap untuk melakukan penulisan proposal, maka kegiatan dilanjutkan ke sesi empat. Sesi terakhir merupakan penulisan proposal PTK. Pada saat kegiatan praktek pembuatan Rencana Pembelajaran dan penyusunan proposal, para guru didamping oleh tim pelaksana PPM, yaitu 3 orang dosen.

Pada awal kegiatan praktek langsung penulisan proposal PTK ini tim pelaksana sempat mengalami hambatan karena jumlah peserta yang tidak sebanding dengan jumlah fasilitator yang tersedia. Selain itu, pada saat workshop pembuatan proposal, ada sebagian guru yang belum dapat mengoperasikan komputer. Oleh karena itu tim perlu membantu mengoperasionalkannya. Setelah dilakukan pelatihan ini guru dapat membuat rencana pembelajaran penelitian tindakan kelas dengan baik dengan menggunakan model pembelajaran. Peserta pelatihan dapat menghasilkan 4 (empat) buah proposal yang dibuat secara berkelompok.
Setelah pelaksanaan kegiatan ini, para guru SDN 001 Rimba Sekampung semakin paham tentang pembuatan proposal penelitian PTK dan sangat menarik minat para guru. Sebagian besar guru mengakui bahwa kegiatan penyusunan proposal ini merupakan hal baru bagi mereka. Oleh karena itu para guru mengharapkan agar kegiatan PPM serupa dapat diberikan lagi pada masa mendatang, agar mereka betul-betul dapat melaksanakan penelitian tersebut pada kelas masing-masing. Keinginan ini juga didorong oleh adanya sertifikasi guru yang sudah dimulai pada tahun 2019 ini.

\section{KESIMPULAN}

Kesimpulan dari pengabdian masyarkat yang dilakukan antara lain kemampuan guru menjadi meningkat dalam mengupayakan pembelajaran yang efektif dengan modelmodel pembelajaran. Guru dapat memahami konsep penelitian tindakan kelas. Guru dapat memahami penyusunan desain penelitian tindakan kelas. Guru menyusun proposal penelitian tindakan kelas. Guru dapat memberikan penilaian laporan penelitian tindakan kelas.

\section{DAFTAR PUSTAKA}

Handayani, S., Nasikh, N., \& Annisya', A. (2017). Peningkatan Kinerja Guru Melalui Kegiatan Pelatihan Penyusunan Proposal Penelitian Tindakan Kelas (Ptk) (Studi Kasus Pada Guru - Guru Ekonomi Di Kabupaten Malang). Jurnal Pendidikan Ekonomi, 10(2), 183-192. https://doi.org/10.17977/um014v10i2201 $7 \mathrm{p} 183$

Mulia, D. S., \& Suwarno. (2016). Ptk (Penelitian Tindakan Kelas) Dengan Pembelajaran Berbasis Kearifan Lokal Dan Penulisan Artikel Ilmiah Di Sd Negeri Kalisube, Banyumas. Khazanah Pendidikan Jurnal Ilmiah Kependidikan, IX(2), 11 . Retrieved from http://jurnalnasional.ump.ac.id/index.php /khazanah/article/view/1062/983

Somatanaya, A. A. G., \& Herawati, L. (2017). Pelatihan Penelitian Tindakan Kelas ( Ptk ) Bagi Peningkatan Karier Guru-Guru 
Sekolah Dasar. Jurnal Siliwangi, 3(1), 169-175.

Wiganda, S. (2014). Pelatihan Penelitian Tindakan Kelas Bagi Guru-Guru SeJakarta Timur. Sarwahita, 11(1), 1. https://doi.org/10.21009/sarwahita.111.0 1

Bahdin, Nur Tanjung dan Ardial. (2005). Pedoman Penulisan Karya Ilmiah (Proposal, Skripsi, dan Tesis) Dan
Mempersiapkan Diri Menjadi Penulis Artikel. Jakarta: Prenada Media

Brotowidjoyo, Mukayat D. (1985). Penulisan Karangan Ilmiah. Jakarta: Akademika Presindo.

Depdiknas Dirjen Dikdasmen Direktorat Tenaga Kependidikan. (2001). Pedoman Penyusunan Karya Tulis Ilmiah di Bidang Pendidikan dan Angka Kredit Pengembangan Profesi Guru. Jakarta:2001. 